\title{
What makes students satisfied? A discussion and analysis of the UK's national student survey
}

Article

Accepted Version

Bell, A. R. and Brooks, C. (2018) What makes students satisfied? A discussion and analysis of the UK's national student survey. Journal of Further and Higher Education, 42 (8). pp. 1118-1142. ISSN 1469-9486 doi:

https://doi.org/10.1080/0309877X.2017.1349886 Available at https://centaur.reading.ac.uk/68296/

It is advisable to refer to the publisher's version if you intend to cite from the work. See Guidance on citing.

To link to this article DOI: http://dx.doi.org/10.1080/0309877X.2017.1349886

Publisher: Taylor and Francis

All outputs in CentAUR are protected by Intellectual Property Rights law, including copyright law. Copyright and IPR is retained by the creators or other copyright holders. Terms and conditions for use of this material are defined in the End User Agreement.

www.reading.ac.uk/centaur 
Central Archive at the University of Reading

Reading's research outputs online 


\section{What Makes Students Satisfied? A Discussion and Analysis of the UK's National Student Survey}

Adrian R. Bell and Chris Brooks

ICMA Centre, Henley Business School, University of Reading, Whiteknights, Reading RG6 6BA, UK; tel: (+44) 118378 7809; e-mails: A.R.Bell@reading.ac.uk and C.Brooks@reading.ac.uk

November 2016

\section{Abstract}

This paper analyses data from the National Students Survey, determining which groups of students expressed the greatest levels of satisfaction. We find students registered on clinical degrees and those studying humanities to be the most satisfied, with those in general engineering and media studies the least. We also find contentment to be higher among part-time students, and significantly higher among Russell group and post-1992 universities. We further investigate the sub-areas that drive overall student satisfaction, finding teaching and course organisation to be the most important aspects, with resources and assessment and feedback far less relevant. We then develop a multiattribute measure of satisfaction which we argue produces a more accurate and more stable reflection of overall student satisfaction than that based on a single question.

NOTICE: this is the author's version of a work that was accepted for publication in the Journal of Further and Higher Education. Changes resulting from the publishing process, such as peer review, editing, corrections, structural formatting, and other quality control mechanisms may not be reflected in this document. Changes may have been made to this work since it was submitted for publication.

JEL classifications: C52, 121, 123

Keywords: National Student Survey, student satisfaction.

\section{Acknowledgements}

We are grateful to Lisa Schopohl for excellent research assistance. We thank seminar participants at the Universities of Reading and Bath for insightful comments. We are grateful for helpful discussions 
with Cherry Bennett, Maxine Davies, Nathan Helsby, Eileen Hyder and Claire McCullogh. We also thank two anonymous referees, Tony Moore and James Walker for detailed comments on an earlier draft. 


\section{Introduction}

The UK higher education system has undergone radical changes over the past decade. The funding formula has altered significantly, so that the bulk of universities' incomes now come from the fees paid by the students themselves rather than from a government block grant. The introduction of the National Student Survey (NSS) in the UK has introduced a heightened focus on the 'student experience' (Gibbs, 2010; 2012), which has engendered several important changes in universities' environments and modus operandi. First, students now feel a sense of empowerment as paying customers and they expect high quality teaching, good facilities, and high standards of organisation and of professionalism throughout their experience (Kay, Dunne and Hutchinson, 2010). Second, universities have become more corporate in their outlook and objectives, entrepreneurially establishing new subject areas and programmes with the objective of increasing student numbers to generate revenue (for instance see the the University of East Anglia (UEA) Plan 2016-20). ${ }^{1}$

Universities compete in an increasingly international marketplace to attract highly qualified students (Chatterton and Goddard, 2000), who in turn are increasingly aware of the relative rankings of universities and departments, with the danger that such rankings then become increasingly ossified and a self-fulfilling prophecy. Achieving a high and rising position in the rankings is now considered a legitimate (and perhaps the most important or even only) objective in its own right rather than being merely a positive side effect of good performance on other, more specific indicators. Consequently, a poorer than expected positioning in the rankings is likely to lead to admonishment of deans and heads of department by university senior managers; the former will in turn pass on their disappointment to the rank and file, who are told that things must improve (Locke, 2014). ${ }^{2}$ Letcher and Neves (2010) point out that universities are interested in student satisfaction for two major reasons: firstly and positively, that it leads to greater retention and academic achievement by the students themselves; and secondly and more selfishly, good ratings of satisfaction lead to good public rankings, which enable universities to enhance their prestige, recruit the best students and fulfill their annual quota for new students. ${ }^{3}$

The present paper aims to contribute to the debate regarding the extent to which students are satisfied with their university experience by conducting a comprehensive analysis of the results of the UK's National Student Survey, completed by over 140,000 undergraduates in 2014. No other survey in the UK has such a comprehensive coverage across both the subject and institutional dimensions and as we discussed above, the results from the NSS are of strategic importance to universities since they occupy such a key position in several rankings. The existence of the NSS data, which are publicly available, provides a unique environment in which to examine student satisfaction on a nationwide basis covering all subject areas taught by each university. We examine subject and regional dimensions, and we also focus on the interlinkages between the various categories of

\footnotetext{
1 https://portal.uea.ac.uk/documents/6207125/12506475/UEA+Plan+2016-2020_final.pdf/5ff04627d120-4808-8fa1-196e57ca370d

2 This then leads to additional pressure on teaching staff and increases the likelihood that some will leave. Of course, attrition from the teaching staff is not necessarily bad if it injects additional dynamism and energy into the faculty through "fresh blood", but this would also depend on the extent to which departing staff were the weaker members of the team or those with the greatest outside opportunities. In addition, research suggests that academics often work long hours for relatively low pay (Walker et al., 2010). ${ }^{3}$ For many reasons, recruiting more students following a period of good NSS figures may lead to greater dis-satisfaction in the future - not only because there would be more competition to secure jobs, but also since resources are spread more thinly and class sizes increased.
} 
questions within the NSS. We explore this rich data source along various dimensions and examine the extent to which scores across the various areas within the NSS provide correlated assessments of satisfaction. Finally, we also examine a multi-attribute approach to calculating an aggregate rating, which could be used to replace the results from the overall rating question, producing more stable and reliable estimates of student satisfaction.

The remainder of this paper is organized as follows. Section 2 discusses the existing literature on the drivers of student satisfaction, while Section 3 presents the National Student Survey and considers the debate surrounding the use of such surveys more generally. Section 4 moves forwards to examine the NSS data from various angles and finally Section 5 reflects on the implications of our findings and concludes.

\section{What are the drivers of student satisfaction?}

The existing evidence in the academic literature regarding student satisfaction is somewhat sparse, geographically very widely spread and mainly focused on the individual student level. There are several existing studies which cover various parts of our analysis, however. A relatively early piece of research is the report for the Higher Education Funding Council for England by Surridge (2008). She conducts a comprehensive analysis of the early years of the NSS, examining the drivers of student satisfaction for the 2005-07 cohorts, including student characteristics, broad subject areas and several institution-level variables.

Fielding et al. (2013) conduct an analysis of the 2006 and 2007 NSS data for nine subjects in the science and engineering areas. They use various stratified approaches to capture and compare satisfaction, reaching wide-ranging conclusions but cautioning on the dangers of comparing between subjects and institutions. Hewson (2011) conducts an analysis of four questions from the NSS for 19 subject areas using a Bayesian Markov Chain Monte Carlo approach, highlighting significant differences between levels of satisfaction by subject area for each question. He also emphasises the sample-selection problems that may exist where certain groups of students may be more likely to complete the survey than others, thus potentially biasing the results, although this issue has not been investigated further in subsequent work.

When students evaluate the quality of a course and reflect on their overall satisfaction, they undergo a cognitive process in which they compare their prior expectations about the quality of the delivery and outcomes with their perception of the corresponding actual performance and outcomes (Zeithaml et al., 1993). Not only cognitive factors, but also emotions can affect satisfaction survey responses (Oliver, 1981). As Mavondo et al. (2004) note, students are variously seen as customers receiving a service (Guolla, 1999), as co-producers of knowledge who share responsibility for their learning with their university (Armstrong, 1995) and as products (Guolla, 1999) which the university then 'places' in the job market. Clearly, the perspective from which students view themselves will influence how they evaluate their satisfaction in an essentially immeasurable fashion.

As Elliott and Shin (2002) put it, "Student satisfaction is being shaped continually by repeated experiences in campus life. Moreover, the campus environment is seemingly a web of interconnected experiences that overlap and influence students' overall satisfaction. What happens 
to students in the classroom is not independent of all other experiences of campus life" (p. 198). Therefore, the quality of the course and aspects of the curriculum (Browne et al., 1998), as well as the campus environment (Borden, 1995), are all argued to be drivers of satisfaction. ${ }^{4}$ In a US study of undergraduate business students, Letcher and Neves (2010) find that the quality of teaching in the specific subject matter has little or no effect on student satisfaction. Instead they find that other factors have a greater impact, including self-confidence, extra curricular activities, careers, and the general quality of teaching. The study uses a student evaluation format to investigate what is important to undergraduates when recording satisfaction with their programmes and university experience. There is an interesting conundrum that Letcher and Neves also discuss, namely that other research has established academic performance to be key to student satisfaction. It is fairly intuitive that students who are performing well and receiving positive feedback will rate a module more highly. But causality could go in both directions: even more intriguing, they quote Pike's (1991) conclusion that satisfaction exerts a greater influence on exam performance than academic performance does on student contentment. Thus happy students perform well, as opposed to high performing students being happy. ${ }^{5}$

Students who are reflecting on the quality of the education that they perceive they have received may bring a whole host of incidental factors into the evaluation process. Further, Merritt (2012) studies general biases in evaluations related to Law schools and states, 'The way in which a professor walks into the room or smiles at the class can affect student ratings much more substantially than what the professor says or writes on the blackboard'. He cites a famous experiment by Naftulin et al. (1973), 'The Dr Fox Lecture', where an actor delivered a lecture of nonsense but with a 'warm manner' (pp. 242 and 239), receiving glowing evaluations.

In summary, the literature cited in this section has illustrated the diverse range of factors that affect student satisfaction, but also that most of the existing evidence is based on small samples, single subject surveys or focus groups. Our approach is quite different in that we use a very large multidiscipline database which facilitates quantitative comparisons of satisfaction by various categorisations. We outline the properties of this database in the following section.

\section{The NSS - A Description and Discussion}

The National Student Survey (NSS) is a questionnaire-based measure of student satisfaction established in 2005 at the behest of the UK government. The survey can be taken by all third year undergraduates at Higher Education Institutions in England, Wales, Northern Ireland and Scotland. The aims of the NSS at the point of its establishment were to audit the quality of courses run by HEIs, to make them more accountable for quality, and to support the decision-making of future university applicants. ${ }^{6}$ The NSS is a cumulative measure of satisfaction (Parker and Matthews, 2001) that takes place towards the end of a student's experience and involves respondents balancing a large number

\footnotetext{
${ }^{4}$ Poor satisfaction can result from a mismatch between delivery and expectations in any of these areas but it has been argued that support services are commonly perceived as less satisfactory than the academic aspects of the courses (Kotler and Fox, 1995).

${ }^{5}$ See also Douglas, McClelland and Davies (2008) who investigate student satisfaction using a Critical Incident Technique in order to develop a new model, arguing that 'service quality is a precursor to student satisfaction' (p.21); and Arambewela and Hall (2009) who found that both educational and noneducational factors were significant variables in explaining student satisfaction.

${ }^{6} \mathrm{H}$ Swain, 'A hotchpotch of subjectivity' The Guardian, 19 May 2009.
} 
of factors to arrive at specific satisfaction measures for each category of question. The NSS comprises a total of 23 questions split into seven categories (the teaching on my course; assessment and feedback; academic support; organisation and management; learning resources; personal development; and finally overall satisfaction). Each question asks students to reflect on their experience and respond on a Likert scale (1-5) from "Very dissatisfied" to "Very satisfied". ${ }^{7}$ These Likert scale responses are then distilled into a binary variable indicating whether students are satisfied/very satisfied or unsatisfied.

While it is increasingly being used as a policy instrument for bringing about changes that enhance the student experience and as a means of competition in rankings tables, student satisfaction surveys in general, and the NSS in particular, have been criticised on a number of key grounds, both philosophical and operational (Sabri, 2013). A particular issue strikes at the core of the purpose of the study - namely whether students themselves are in the most appropriate position to assess the quality of their education, in particular while they are still studying and the survey responses will probably be weighted more towards students' most recent experiences which are at the forefronts of their minds. An entirely different approach would be to ask alumni this question several years after they graduate (for instance as publications such as The Financial Times does to inform Business School rankings) and have had time to reflect on whether what they learned was useful rather than merely entertaining. Moreover, one could question whether students are in fact the best placed stakeholders to comment on the quality of their education at University.

Some dangers of un-scientific and top-down metrics of student satisfaction are pointed out by Gruber et al. (2010) who discuss a new measurement tool for student contentment. Their study was motivated by the decision to introduce tuition fees in German universities (since reversed) as the authors believed that institutions would now have to treat their students as customers. They felt that the UK was a leader in this area whereas Germany had not paid attention to either measuring or trying to improve the student experience. They point out that due to the unique nature of higher education, service quality cannot be measured objectively (p.107). They rightly explain that the different stakeholders - students, government and professional bodies, for instance - have very different measures of quality. They also 'regard service quality as an antecedent to satisfaction' ( $p$. 108). Intuitively, they develop the study with the belief that universities can only satisfy their students if they know what they actually want rather than basing the service delivery on what they perceive that students want (p. 108). This may sound rather obvious, but Gruber et al. refer to studies demonstrating that academics and administrators prefer to rely on their own view of what students need. The study actually finds that student satisfaction is correlated to the satisfaction with lecturers, university facility quality, and the relevance of teaching to practice. Their paper describes an experiment with two samples of students from one University in Germany and the authors admit

\footnotetext{
7 Throughout this paper, we use a range of parametric statistical approaches to the analysis of student satisfaction. However, it is important to note that strictly, the mean of a Likert scale is undefined and therefore one should interpret the statistical inferences undertaken on these variables with caution. We observe, though, that a comparison of the means and of the medians paints a very similar picture. In addition, our unit of analysis is the course or course collection at a particular university and not the individual student scores. As such, all of the satisfaction measures we employ in the database are continuous and no longer on a Likert scale as they are averages, albeit bounded between one and five.
} 
therefore that the results are not even representative of the whole student population in that country.

Methodologically, the validity of the NSS as a measure of the student experience has been questioned (Yorke, 2009). Thus, from a practical perspective, the NSS has not been without its critics regarding several aspects. First, there is evidence that universities may be prone to 'cheat' the scores. ${ }^{8}$ Second, it has been argued that the satisfaction scores of 'the vast majority of institutions fall within a narrow range that is covered by sampling error' and in such circumstances the rankings that are based on the survey will have little meaning. Third, the need to 'keep the customers happy' may engender a fall in standards where students are spoon-fed and marking is unduly lenient in order to raise the scores the easy way. This, dovetailed with the heightened emphasis on transferrable skills and employability, may encourage universities to increasingly act as training colleges (Taylor and McCaig, 2014) at the expense of the development of deeper intellectual and analytical abilities.

There is thus likely to be considerable sampling variation in average NSS scores for each individual course from one year to the next since each group of students will complete the survey only once. There is also evidence that students may misinterpret questions or believe that specific questions do not apply to them given their subject area and the nature of the teaching they receive (Yorke, 2014, p. 557). Thus perceptions of quality, and therefore relative ranking positions, may vary erratically from year to year despite the course structure, teaching faculty, facilities and assessment approaches remaining ostensibly the same. ${ }^{9}$ It is clear that while the scores are certain to vary from one cohort to another for a specific programme within a given school, academics fear that their institutional managers will expect them to rise year-on-year.

The results from the NSS were identified as early as 2007 as being important for student selection (Asthana and Biggs, 2007; Hewson, 2011), and indeed this is one of its core purposes, although the overall ranking of institutions is more influential for applications (Gibbons et al., 2015). Yet there is a clear danger that the information contained within the survey findings is likely to be consumed in a very undiscerning way by prospective degree course applicants, who have no detail on the contexts of how or why a particular set of satisfaction scores arose, and could as a result make worse subject or institution choices ex post than they would have done in the absence of any satisfaction information. Any attempt by the institution concerned to explain or justify low ratings for a particular course will be summarily dismissed as weak excuses or sour grapes. The existence of the survey is even argued to have fundamentally changed the student-teacher relationship (Gornall and Thomas, 2014) and with it students' notions of what a university is for (Collini, 2012).

It appears that the future of the NSS itself is currently up for discussion. ${ }^{10}$ It is expected that the new TEF (Teaching Evaluation Framework) will somehow have an aspect of student satisfaction metric to

\footnotetext{
${ }^{8}$ It was reported that London Metropolitan and Kingston Universities manipulated the scores at their institutions - see L. Harvey, 'Jumping through hoops on a white elephant: a survey signifying nothing' Times Higher Education, 12 June 2008.

${ }_{9}^{9}$ Naturally, University teachers and administrators may respond to a poor set of NSS scores, although if the concerns of the departing cohort are not consistent with those of the new cohort, there is a danger that such introduced changes may not be welcome.

10 Times Higher Education, 23 July 2015.
} 
feed into it and evidence from the NSS was used to inform the current Green Paper discussed earlier. The direction of the current debate suggests that the NSS' days in its current form are numbered and instead student engagement should be a focus of the questionnaire alongside student satisfaction. A review of the NSS by HEFCE found that the survey does not take account of student engagement with learning, and recommends 11 new National Student Survey of Engagement (NSSE)-style questions by 2017. ${ }^{11}$ A report entitled 'Dimensions of Quality' by Graham Gibbs argues that quality can gauged by various measures of class size, teaching staff, the efforts students make and the quality of feedback they receive. Relatedly, the 'HEA UK Engagement Survey' was piloted in 2013 and larger trial took place in 2014. Yet the broad principles behind the NSS have received strong support by the UK government, which has argued that it has 'good internal consistency' and 'does not need radical alterations'. ${ }^{12}$

The Student Academic Experience Survey (SAES) is a complement to the NSS which asks fundamentally different questions. The SAES was introduced in 2006 to examine the impact of increased fees on students' perceptions and priorities (Buckley et al., 2015). The survey is now conducted annually and is run jointly by the Higher Education Policy Institute and the HEA. In 2015, around 15,000 students completed the survey, representing a much lower response rate (22\%) than that achieved by the NSS. While we do not have data from the SAES, its findings have informed and motivated our research questions.

Although each student has (almost invariably) only one undergraduate university experience, and may make their judgements on a different basis and using different ordinal values for a given received level of quality, the fact that every student faces the same questions and must provide answers on the same scale means that comparisons across fields and institutions are possible within the NSS. We should note, however, that it might be the case that certain subjects have an approach to teaching that is more closely aligned with what the NSS measures, which would make comparisons across subjects hard (see Gibbs, 2010, p.46). This could even extend to cross-university comparison due to the differing subject mixes within them (Fielding et al., 2010, p.347). Many criticisms have been levelled at the NSS, but most are generic to any method of gauging students' views of their university experience and within its own genre, it could be viewed as a comprehensive and robust barometer of student satisfaction and therefore worthy of quantitative analysis.

\section{A Quantitative Analysis of the Results from the National Student Survey}

\subsection{How does satisfaction vary by subject area?}

We employ data from the 2015 National Student Survey. ${ }^{13}$ Tables 1 and 2 summarise the overall satisfaction measures on the 1-5 and percentage of students satisfied scales separated by Higher

${ }^{11}$ The NSSE is a US initiative, similar in spirit to the NSS but focused on a smaller number of specific subject areas. The NSSE asks a larger number of more penetrating questions than the NSS concerning the extent to which students have put efforts into their studies and the opportunities to learn that have been made available to them.

12 'UK review of information about higher education - National Student Survey - A literature review of survey form and effects, by DELNI, HEFCE, HEFCW and SFC, 2015.

${ }^{13}$ We obtain the data from the Planning Office at our own university, but they are also publicly available from the Higher Education Funding Council for England's web site:

http://www.hefce.ac.uk/lt/nss/results/2015/. 
Education Statistical Agency (HESA) subject area. ${ }^{14}$ It is clear that while there is very considerable variation across individual courses, when aggregated across universities to the subject area level, there is much less variation. Students in the media studies area are the least satisfied of all on average (score of 4.02 on a 5 point scale and $79.77 \%$ of students satisfied), followed by general engineering (4.09 and $82.43 \%$ ), while students of clinical dentistry ( 4.65 and $96.38 \%$ ) and then veterinary science $(4.44$ and $92.88 \%$ ) are the most contented. It would be tempting to conclude that highly specialised, vocational courses tend to be most popular while those which are much broader in scope with no obvious career path are less favoured; yet the average evaluations in the classics, philosophy and theology fields are also very high. In general, it therefore seems that students prefer subjects where there is a correct answer rather than having to engage in a debate. This disparity in satisfaction might additionally relate to the attractiveness of studying at the types of universities that offer these subjects (for example if classics is only taught at popular universities with good facilities), but the finding is also suggestive that a more nuanced explanation of student satisfaction is required that examines a range of potential factors as we attempt to do in this study. Almost no existing research addresses this question with which we can compare our findings. Focusing on Art \&Design specifically, York, Orr and Blair (2013) also use the NSS and reveal that it received lower evaluations than most other subjects in 2012, a finding which Yorke (2014) associates with the discipline having a disproportionately large number of part-time teaching staff. Although we also find that this subject ranks at the low end, the others that we highlight (e.g., media studies) perform even worse.

Considering the shape of the distributions of satisfaction within each subject area in Tables 1 and 2 reveals some further interesting patterns. There are some specific courses receiving very poor evaluations including those in nursing (minimum score 2.6 , minimum just $29 \%$ of students satisfied), health and community studies (minimum 2.4 and 24\%), and electrical engineering ( 2.5 and 17\%); these individual very low evaluations increased the spreads of scores and of percentages satisfied. At the other end of the scale, most course areas had at least one (measured by the maximum) or several (measured by the $95^{\text {th }}$ percentile of the distribution of scores) courses that were able to achieve a $100 \%$ satisfaction rate.

\subsection{Is there a regional dimension to student satisfaction?}

In Table 3 we present summary measures for satisfaction separated into 12 regions. It is plausible to expect differences in satisfaction levels across regions, arising both from differences in relative costs of living but also as a result of the different kinds of lifestyle that each region may offer. Home-based students in Scotland will also not be paying tuition fees as they would if they studied south of the border and it might be that this enhances their feeling of well-being. The figures in the table indicate a statistically significant difference in the average level of satisfaction across the regions, although the absolute magnitudes of the differences in the Likert scale measures are modest. The results suggest that those studying in Northern Ireland are the most contented, with over $90 \%$ of students satisfied with their courses overall; at the other end of the scale are Londoners, who are the least satisfied. Here we can assume that within parts of the UK the majority of students are home,

${ }^{14}$ The NSS raw data includes 108 separate degree subject classifications, which is not manageable for analysis and we therefore collect them into cognate groupings according to the 45 'cost centres' reported by HESA. 
whereas in London, we can expect students from all over the UK. Therefore, local students in Northern Ireland pay just $£ 3,805$ (students from the rest of the $U K, £ 9,000$; from other parts of the EU $£ 3,805) .{ }^{15}$ Belfast is also the most affordable city for living within the UK according to the same source. There are therefore two possible environmental factors that drive these results, as students may think they are receiving good value for money and also they can have a reasonable standard of living on the available student loan. The London result may be driven from the opposite direction, with most home students paying $£ 9,000$ fees and finding it hard to make ends meet in an expensive place to live. In addition, their residence may potentially be a long tube ride away from the study buildings, leading to a feeling of isolation from their classmates and a lack of cohesion with the school and other programme participants and staff . ${ }^{16}$ Indeed, in a recent survey London was reckoned to be one of the worst places to live in the UK because of its high rents and long working hours. ${ }^{17}$ Students in London may find it harder to become involved in recreational activities such as sports with their cohort, and this may negatively affect their well-being. ${ }^{18}$ In addition, there will be more international students within the London student body who are drawn to studying in the capital, and it may be possible that they evaluate their experience differently and perhaps more critically.

\subsection{Which aspects of their provision are students most (dis)satisfied with?}

Ironically, while the focus of the government (as demonstrated through the recent Green Paper and other reports) appears to be squarely on university teaching, this aspect of degree provision appears to be working very well and generating high levels of satisfaction. Nationally, $91 \%$ (4.2 on a 5-point Likert scale) of students are satisfied that staff are good at explaining things, while $89 \%$ (4.3/5) agreed or strongly agreed that staff are enthusiastic about what they are teaching. On the other hand, the scores are much lower for assessment and feedback, with only 69\% (3.8/5) of students agreeing or strongly agreeing that feedback was prompt and $68 \%(3.8 / 5)$ agreeing that feedback had helped clarify matters that they had not previously understood. Course organisation was also rated relatively poorly (77\% satisfied; 4.0/5), as was the Students' Union or Guild (68\% satisfied; 3.8/5). ${ }^{19}$

It is possible that there are spillover effects between the categories of questions used in the survey so that, for example, a particularly bad experience with accommodation or even a trivial mix-up with room bookings at an inopportune moment close to the survey completion date will engender a jaundiced view of the entire educational experience, irrespective of how good the quality of course delivery had been. ${ }^{20}$ Land and Gordon (2015) argue that student surveys unhelpfully encourage respondents to conflate service satisfaction with teaching excellence and 'draw heavily on the logic

\footnotetext{
${ }^{15} \mathrm{http}$ ///www.qub.ac.uk/home/StudyatQueens/UndergraduateStudents/FeesandFunding/.

${ }^{16}$ Interestingly, however, the introduction of $£ 9000$ fees did not reduce the nationwide percentage of satisfied students, which remained at 86 in both 2014 and 2015 ('NSS 2015: £9k tuition fees fail to dent satisfaction' by C. Haveral, 13 August 2015, Times Higher Education no. 2216).

${ }^{17}$ http://www.telegraph.co.uk/finance/economics/11976033/Forget-London-these-are-the-best-placesto-live-in-the-UK.html.

${ }^{18}$ See Gilman (2001) for a discussion of the positive effects of recreation and sports on high school students.

${ }^{19}$ In the UK, the Students' Union has a dual role - both as a political campaigner and activist for student issues locally and nationally, and second, as an organiser and venue for student clubs, societies and entertainment.

${ }^{20}$ The reverse problem where students focus on a narrow range of information when answering the survey questions has been termed 'cherry picking' - see Callender et al. (2014).
} 
of student as consumer' (p.21). They propose that the NSS more formally separates the two issues into individual sections. Thus, as things stand, the satisfaction measures ought to be viewed as general indicators of overall happiness with the provision rather than specific categorised viewpoints. The very existence of the NSS has fostered and encouraged a sense of student activism sinc, the survey can be used as a weapon of revenge for any disaffected students who feel that their experience has fallen short of expectations.

Tables 4 and 5 present Pearson correlations between the responses to each section in the NSS, employing the Likert scale and percentage satisfied measures respectively. As the tables show, and as one might expect, the responses to each set of questions, averaged across all students on all courses and at all institutions, are highly positively correlated, which confirms a similar finding by Fielding et al. (2010) using our updated sample and wider range of course areas . For example, the correlation between the scores on 'teaching on my course' and 'learning resources' is 0.645 despite the obvious possibility that excellent teaching could take place inside a dilapidated pre-war building. In this context, the resources explicitly referred to in the questions relate to library resources, IT, and specialist resources respectively. The 'personal development' score is almost as highly correlated with 'academic support' (nearly 0.8 ) and with 'organisation and management' (0.75) as it is with teaching quality (0.83). The correlations are uniformly slightly lower in Table 4, since constructing the satisfaction variable in this way does not take into account strength of feeling because the method of construction of this variable effectively translates it into a 0-1 as students are either satisfied or they are not. The numbers in Table 3 are nonetheless high again, indicating that, by and large, at the level of a course or group of courses, students are either happy with everything or unhappy across a range of measures. The only exceptions are present in the final columns of both tables, which measure how contented respondents are with their Students' Union or Guild, and while still always positive, this variable has much lower correlations with other measures - typically of the order 0.25 .

Following Langan et al. (2013), ${ }^{21}$ Table 6 presents the findings of two exploratory regressions to determine which of the specific areas within the NSS questionnaire students appear to focus on when they answer question 22 to express their overall satisfaction. This issue is of particular interest since, as discussed above, the overall satisfaction score is the one that forms the basis of most of the ranking measures, and which is most discussed in the media and most highlighted on university web sites. The academic aspects of provision are typically well received, but support services (e.g. careers) may be less satisfactory (Kotler and Fox, 1995) and students may even conflate their satisfaction with their social lives into their overall rating (Elliott and Shin, 2002).

The regressions that give rise to Table 6 are conducted on all 4465 course-university combinations as described above; the dependent variable is the overall satisfaction measure - either the Likert score (middle column) or the percentage of students who are satisfied (right-hand column), while the independent variables are the scores for each of the sections. This is a legitimate specification and not a tautology since the overall satisfaction scores arise from a specific question in the survey and are not direct aggregates of the component scores. It is clear that all of the component scores are highly significantly (at the $0.1 \%$ level or even lower) and positively related to overall satisfaction,

${ }^{21}$ Unlike Langan et al., however, we retain Ordinary Least Squares whereas they use the much less well known "random forests analysis" approach. 
although respondents seem entirely unfazed by the quality or otherwise of their Students' Union, which is not significant even at the $10 \%$ level and has parameter values which are several orders of magnitude lower. In terms of the other specific section scores, students appear to put most emphasis on teaching quality (as Fielding et al., 2010, p.360, noted), followed by organisation and management and then personal development, when arriving at their overall rating, with the parameter estimate for the first of these being more than double that of the latter two. Universities may be relieved to note that, while still highly statistically significant, the magnitudes of the parameters on assessment and feedback, where satisfaction scores are generally lower, are a tenth of that on teaching effectiveness. ${ }^{22}$ Similarly, the parameter estimate on learning resources is of small size, suggesting that it plays a minimal role in overall happiness despite the huge sums that universities have spent on infrastructure, which some have dismissed as vanity projects, in recent years. ${ }^{23}$ Comparing our results to those of Langan et al. (2013), we observe broadly similar findings as for their (longer) three-year sample covering a narrower range of subject areas, but to a greater extent. Specifically, we observe an even stronger role for teaching and even weaker for assessment and feedback.

In Table 7 we proceed to summarise the mean satisfaction scores (1-5 scale, left hand panel) and the percentage satisfied (right hand panel) split in a pairwise fashion for a number of sub-samples, also presenting Welch's t-tests of the difference between the means of the two sub-samples, allowing for uneven sample sizes and not assuming equal variances. Part-time students are more satisfied than their full-time counterparts, since their mean score is higher, as is the average percentage of students satisfied, although the difference between the two groups is not statistically significant ( $t$ value: $-1.1, p$-value 0.3 for the average score and $t$-value: $-0.8, p$-value 0.4 for the percentage satisfied). This could be expected as many part-time undergraduate students are either mature students, or students who enter university from a non A-level route. Such students have different motivations from those who have moved straight into university from school - perhaps seeing access to University as a major lifelong achievement which then impacts on their own student experience.

Do institutions with an elite image always obtain high satisfaction scores? A quick review of the 2014 NSS data at the aggregate level shows that Oxford ranked 15th, Cambridge 31st and the LSE 135th. How can this be explained ${ }^{24}$ Elite universities do not charge higher fees than the remainder of the sector, as almost all universities elected to set them at the capped value of $£ 9000$ for home undergraduate students. Could we be facing two different approaches to image within UK universities? Under this image construct, some of the leading internationally recognised universities in the UK are concentrating on their research brand, potentially to the detriment of their interest in student satisfaction, as this measure does not impact on these types of international university rankings. In parallel, students select to study at these institutions for something other than to be satisfied with their experience of teaching and learning. They want to receive a degree from a university with an internationally leading image and join a global network of peers and alumni. It therefore follows that such universities are never going to have to compete on satisfaction to attract students. The remainder of the UK sector must fight for students and needs to excel nationally in

${ }^{22}$ It may be that students are basing their scores on how positive their feedback has been, rather than its quality.

${ }^{23} \mathrm{http} / / /$ www.theguardian.com/education/2015/may/05/campus-universities-building-projects.

${ }^{24}$ It may also be the case that students at elite Universities have much higher expectations due to a sense of entitlement, which may then effect satisfaction scores. 
the league tables such as those of The Guardian and The Complete University Guide, and such universities are making much more effort to ensure that students who choose their programmes leave extremely satisfied with their experience.

Yet if we examine the results within the broader entire Russell group ${ }^{25}$ in the second panel of Table 7 , overall satisfaction at these universities is statistically significantly higher by around 0.06 on a 5point scale and by one in percentage terms; the minima and medians are also higher for Russell group than for non-Russell group universities. Similarly, when we separate universities into two groups according to whether they are in the Top 400 QS World ranked or not (the fourth panel of Table 7), we observe a similar picture that the more prestigious universities engender (statistically significantly) higher levels of satisfaction, although a larger number of universities (44) hold this designation compared with the Russell grouping (24 universities).

This result is perhaps surprising since it is commonly believed that those at Russell group universities are excessively focused on their research to the detriment of students and teaching activities. Land and Gordon (2015, p.21) argue that there is a 'pronounced disparity' between the financial rewards for research excellence versus teaching excellence, which over time is bound to have an effect on the behaviour and strategic choices of faculty. It may thus be that new universities therefore focus on different kinds of ranking measures where they can excel, as the Huddersfield experience documented by Thornton (2014) shows. ${ }^{26}$ For example, many universities have now established targets for having at least a specific percentage of their faculty being professionally qualified teachers and growing the percentage of qualified teachers is a key aspect of the 'professionalisation' of teaching.

It is possible that these high scores in student evaluations for elite institutions are merely manifestations of brand loyalty, so that they are punished to a far smaller degree for failing to meet expectations than their less renowned counterparts. Such students may internalise their problems with service failures, believing that it must be their own expectations or judgements which are faulty since the hallowed institution, with iconic heritage buildings, must be beyond reproach. The reputation of a university has been shown to affect student retention rates and loyalty (Eskildsen et al., 1999; Nguyen and LeBlanc, 2001; Helgesen and Nesset, 2007). Brand and the university's position in the league tables are highly correlated and both will affect the ability of the institution to attract high calibre students (Palacio et al., 2002) and will also improve other metrics such as employment data following graduation.

We also separate universities into whether they are specialist institutions, which we define as operating in four or fewer subject areas, finding, perhaps surprisingly, that mean scores and the percentage of students who are satisfied are both lower than at more broad-based universities, although not significantly so. The largest difference between sub-groups appears when we separate universities into two sub-groups according to whether they were established before 1992 - the socalled 'old universities' or whether they were established after that date. New universities have

25 The Russell group is a mission group of 24 UK Universities representing what many would consider to be the elite institutions.

${ }^{26}$ The University of Huddersfield set, and achieved a target of having $100 \%$ of teaching staff being professionally qualified teachers or the equivalent, and at the same time (although no causality can be necessarily inferred) their student satisfaction scores increased. 
highly significantly lower levels of satisfaction (a more than three percentage point difference in student satisfaction), with the former having lower mean, median and minimum levels of satisfaction and higher variances.

\subsection{Single attribute versus multi-attribute satisfaction measures}

We could categorise the approaches to measuring student satisfaction according to whether they attempt to evaluate it along a single dimension ("Overall, are you satisfied with your experience?" or "Overall, how satisfied are you?") or along several separate dimensions - single attribute and multiattribute methods respectively. As described in Section 3 above, the National Student Survey includes a total of 23 questions comprising both those in each of seven categories and also a separate question 22 which asks respondents to evaluate their overall satisfaction. Thus, from that perspective it is a slightly odd creation since arguably, given the detailed information in each category, question 22 is superfluous. Nevertheless, the majority of league tables (and indeed universities' own advertising) focus exclusively on the overall question and entirely ignore the information contained in the others unless they have a specific interest in one of the aspects (e.g. improving assessment and feedback scores).

Using a sample of students from an unnamed upper Midwest university in the US as an illustration, Elliott and Shin (2002) argue and demonstrate that an aggregate score which weights a set of individual attributes is likely to embody more valuable information than a single overall measure. They argue that this may arise because the ordering of questions within a survey could influence the outcome. For example, their responses to the most recently completed questions are likely to be uppermost in students' minds when they complete the overall question at the end. Asking students to reflect on their overall satisfaction in such an abstract manner may encourage cherry-picking where they disproportionately base their evaluation on one or two highly memorable events rather than taking a holistic perspective; this is far less likely to be the case when questions are framed in a more specific way and relate to a single aspect of provision such as the quality of the library resources. Respondents may also suffer from questionnaire fatigue so that their answers become less and less well considered as the survey progresses. ${ }^{27} \mathrm{~A}$ further possible issue is the occurrence of errors where students' intended responses based on their actual experience do not match the answers they select. In all four such cases a multi-attribute diagnostic that incorporates the results from many questions is likely to provide a more accurate representation of students' true underlying but latent actual levels of satisfaction.

Motivated by these arguments, we take up Elliott and Shin's suggestion and extend their analysis to the multi-subject, multi-university dataset on the NSS that we analyse. We do not have access to the individual questionnaire responses completed by each student, and so we adapt their approach somewhat to focus at the level of an institution and course collection. More specifically, we run a regression (line of best fit), where the dependent variable is either the Likert-scale satisfaction score or the percentage of students who are satisfied - in both cases for question 22 . The regression includes an intercept plus the scores for each of the component areas, and the fitted line then gives the average relationship between the response to question 22 and those in the individual area

\footnotetext{
${ }^{27} \mathrm{~A}$ possible response to this issue while retaining the integrity of the questionnaire would be to randomise the order of the questions.
} 
covered in the questionnaire. We then take the regression results reported in Table 6 and employ the parameter estimates as weights to construct synthetic overall measures for the Likert scale variable and the percentage of students satisfied, which are effectively the fitted values from the regression. So we could write, for example, for each course collection $i$ at a given institution:

New_satisfaction_score $e_{i}=-1.073+0.489 \times$ teaching score $_{i}+0.030 \times$ assessment\&feedback $_{i}+0.194 \times$ academic_support $t_{i}+0.286 \times$ organisation\&management $_{i}+0.055 \times$ learning_resources $_{i}+0.212 \times$ personal development ${ }_{i}+0.0004 \times$ Students'_Union $_{i}$

and

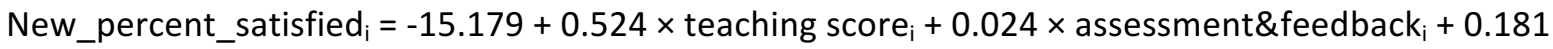
$\times$ academic_support $_{i}+0.262 \times$ organisation\&management $_{i}+0.058 \times$ learning_resources $_{i}+0.159 \times$ personal development ${ }_{i}-0.004 \times$ Students'_Union $_{i}$

Clearly, it would be possible to use a different set of weights - for example, by giving each group of questions the same prominence so that we take a simple average. However, the approach that we have outlined above has the advantage that the function employed to artificially construct overall measures will preserve the relative importance that a typical (more specifically, the mean) student assigns to each category. Therefore, by construction, the overall level of satisfaction estimated from this function will be identical to their actual level of satisfaction as expressed in their response to question 22. For all other course-institution combinations, the estimated levels of satisfaction may differ from the answers to question 22 by lesser or greater extents. Table 8 examines this point in detail. The first panel of the table presents the mean, standard deviation, skewness and kurtosis of the proposed new multi-attribute-based satisfaction measures for both the Likert scale score and the percentage of respondents who are satisfied. It is evident that the weighting functions achieve the desired objective of creating a more stable measure which has an identical mean but a much lower spread of observations, with a lower standard deviation and both skewness and kurtosis that are closer to zero.

For the majority of course collections at each institution, the difference between the actual scores and the artificially constructed composite measures remain very modest, but in some cases there are spectacular changes. The remainder of Table 8 (Panels B to E) report the ten largest risers and fallers for the 1-5 scores and percentage of students satisfied respectively. In these cases, and many others to a slightly lesser extent, the differences in the pictures painted by the composite measure and by the responses to question 22 are very stark. For example, focusing on the very largest changes of all, Ocean Sciences at Southampton Solent University received an average rating of 4.2 on a 1-5 scale with $100 \%$ of students satisfied or very satisfied overall yet the multi-attribute model would place them much closer to the mean with a rating of 3.2 and only $60 \%$ of students satisfied. On the other hand, Fine Art at the University of Bedfordshire received an average score of 3.5 with $55 \%$ of students satisfied, yet the multi-attribute approach would present them with a score of 4.3 and $82 \%$ satisfied.

Further examining this list, it is clear that the big movers are situations where anomalies have arisen where the overall scores do not tally with those for the individual component areas by a big margin and therefore there it is highly likely that the overall score has failed to capture the true levels of contentment of the respondents. The common features of this list of course collections is that they 
all have relatively small numbers of respondents completing the questionnaires (albeit all still within the NSS reporting requirement of at least 10 respondents representing at least a $50 \%$ response rate). To illustrate this in more detail, Table 9 presents the component and overall scores for two of the course-institutions from Table 8 - although we conduct this analysis on all courses and institutions in the sample, here we draw out two extreme cases as exemplars.

Oceanic Engineering at Southampton Solent University scored 4.2 overall with $100 \%$ satisfied, yet not a single one of the component scores are anywhere near this level - for example, teaching satisfaction is at 3.7 (78\% satisfied) and organisation and management, the second most influential sub-category according to our results in Table 6 , is at a relatively poor 2.7 (33\% satisfied). Our multiattribute-based estimate would give an overall satisfaction of $3.2(60 \%)$ satisfied, which is far lower but well within the range of the component scores. Turning now to the biggest change at the other end, Electronic and Electrical Engineering at the University of East London received an overall satisfaction rating of 2.8 ( $17 \%$ satisfied), yet none of the component measures are this low (except Assessment and Feedback, with a score of 2.7 but even here $34 \%$ of students are satisfied). Crucially, the Teaching on My Course and Organisation \& Management scores are 3.3 and 3.5 respectively. Again, the overall result appears anomalous and the multi-attribute-based estimate would be 3.3 (51\% satisfied), which appears much more plausible and in line with the figures for the constituent areas.

What unites these two illustrations is that the total population of students (12 and 17) and consequently the number of respondents (10 and 12 respectively) are very low and in such situations, it is easy for an error in understanding or completion by two or three individual students to have a profound effect on the outcome. Although these are the most extreme illustrations, they are by no means isolated examples: the use of our methodology results in changes of more than ten in the percentage of satisfied students for 268 course collections ( $6 \%$ of the total), while 1262 change by at least five percentage points ( $28 \%$ of the total). Such changes would be taken very seriously by the institutions concerned, and in all cases would be likely to represent the difference between recriminations and celebrations.

From the fundamental principles of statistics, the law of large numbers ought to imply that an average (weighted) measure of satisfaction should be more stable over time (have a lower standard deviation) than a measure based on a single overall score. In order to test this, we repeat the above analysis to construct synthetic overall scores based on the weightings of the components for each of the seven years 2009-2015 for which data from the National Student Survey are available on a comparable basis. ${ }^{28}$ We then construct, separately for each course collection at each institution, the standard deviation of these synthetic composite scores and compare it with the standard deviations of the actual overall scores (both for the scores measured on a 1-5 scale and the percentage of students satisfied). The results, reported in Table 10, present the average of these standard deviations across all course collections at all institutions clearly show that indeed the synthetic measure is more stable over time. For example, in the case of the percentage of students satisfied, the standard deviation for the synthetic measure is 5.95 compared with 6.91 for the original

\footnotetext{
${ }^{28}$ We employ the same weightings as above and apply them to all years, although it would of course be possible to optimize separately for each year.
} 
measure; the standard deviation of the synthetic measure is also lower for two thirds of course collections than the results from question 22.

\section{Discussion, Conclusions and Reflection}

This study systematically examines the cross-sectional variation in responses to the National Student Survey, covering all subject areas and universities that participated, and as such it has a broader subject coverage than existing work. Initially summarising the data, we find that students of clinical subjects or humanities are most satisfied, while those on media studies and general engineering courses are the least so. From a geographical perspective, students in Northern Ireland and the Northeast are the most contented and those in London the least. We next examine the interrelationships between the sub-categories of questions asked in the survey, finding perhaps surprisingly high correlations between areas where the quality of service may not necessarily be expected to go together. We showed that when determining their overall level of satisfaction in question 22, as existing research by Langan et al. (2013) has shown, students appear to place most emphasis on teaching, course organisation and personal development with very little on assessment and feedback or how happy they were with their Students' Union. Finally, we showed that in pairwise comparisons of sub-groups, students on part-time degrees, at Russell Group universities, at non-specialist institutions, at universities in the QS Top 400, and at old universities, were more satisfied than in their counterparts.

Our findings lead to several interesting policy implications. First, many universities have actively identified improving the assessment and feedback aspects of their NSS as a strategic priority, given that in most cases these scores are lower than for other parts of the survey. Whilst this is undeniably a laudable objective in its own right, it appears that the primary motivation for this focus in many instances is in fact as an indirect way to improve the overall scores. Our regression results suggest, however, that the role of feedback and assessment in influencing the summary outcome is extremely small (as Fielding et al., 2010, also note) and thus universities would be better directing their efforts at further increasing the sub-scores on teaching, and to a lesser degree, course organisation and personal development. A further concern is that when students present their scores on the feedback that they have received, they are actually reporting on its positiveness and not its quality or timeliness (Boehler et al., 2006).

Second, our results suggest that part-time students are significantly more satisfied than their fulltime counterparts, perhaps reflecting that Universities have offered a variety of other benefits including access to courses to mature students with families and life-long learning opportunities. Yet part-time courses are increasingly under pressure in the UK and if they are not carefully nurtured, will continue to decline in number. ${ }^{29}$ For example the Open University has reported losses for $2014 / 15$ of $f 7$ million on the back of student numbers falling by $7.2 \% .{ }^{30}$ Third, we suggest that for

\footnotetext{
${ }^{29}$ See, for example, the BBC website news article by A. Harrison, 14 March 2013, "'Dramatic decline' in part-time university students in England".

${ }^{30}$ https://www.timeshighereducation.com/news/open-university-posts-ps7m-loss-student-numbersslump
} 
universities which are desirous of improving their NSS scores, there are probably no silver bullets although encouraging higher response rates is the quickest fix. ${ }^{31}$

Third, the multi-attribute approach proposed by Langan et al. (2013) and which we investigate further here, combining the responses to all question areas in the survey, has advantages - both theoretical and in practice. We find that the differences between the single question overall satisfaction scores and those based on the synthetic calculation approach combining many attributes result in very considerable changes in measured satisfaction for more than a quarter of the sample. We would therefore recommend that universities' own appraisals of student satisfaction and those that feature as key ingredients in league table rankings should employ such a measure or they could report both the raw and the modified overall satisfaction scores.

It is common for scores for a given course collection at a given institution to vary from one year to another, sometimes substantially. Yet typically, the structure of courses and their organisation, the teaching staff, and the facilities all change relatively slowly over time in most cases. The only factor changing systematically from one year to another is the student body itself and so perhaps these year-to-year variations say more about the students than the quality of provision. Despite this, anecdotal evidence appears to suggest that senior university managers are failing to grasp that the results from the NSS are examples of realisations of a stochastic process so that scores may rise and fall over time as a result of essentially random factors. Hence modest falls are considered disasters, as evidence that things are going backwards when this may not be the case, and the unreliability of the single question overall satisfaction measure will surely exacerbate this. We have shown that broad-based aggregate measures are more stable over time than those based on the responses to a single question. Such additional stability would be highly welcome within institutions, and would enable them to assess the underlying quality of their provision with greater precision and plan more effectively.

Finally, we should note that it may be inappropriate to draw too strong a set of prescriptives from our analysis, however, since students' subjective perceptions of the quality of their programme will be evaluated relative to their prior expectations and the latter is unobservable. Therefore, students showing the least satisfaction may have received a high quality learning experience but nevertheless be the most disappointed as their levels of anticipation were so high. Such an effect might explain why, for example, students in the UK were less satisfied on average along all dimensions than those in the US (Mai, 2005, p.874). ${ }^{32}$ Relatedly, it is well established that student demographics themselves may affect their perceptions when completing the questionnaire. For example, research has suggested that the youngest and oldest students tended to be happiest, with those in between the least happy (Blanchflower and Oswald, 2004) although the gender of the respondent does not have a discernible effect (Chan et al., 2005).

Further, it may be the case that the differences between levels of satisfaction across sub-groups may merely be separate manifestations of the same phenomenon - for example, that new universities

\footnotetext{
31 Unreported results show that increasing the response rates has a significant positive effect on satisfaction, consistent with the notion that the most aggrieved students are the keenest to complete the survey, while those with more moderate or positive views are more likely to require prompting. ${ }^{32}$ Further light could be shed on this by the introduction of entry surveys to measure student expectations of their forthcoming University experience.
} 
have weaker reputations (not being members of the Russell group and less commonly within the QS Top 400 than old universities) or that are more likely to offer the less popular subjects such as media studies. Therefore, further research could fruitfully employ a multiple regression-type model that attempts to tease out the separate effects of these various factors (e.g., university reputation, class sizes, demographics of the student body, subject area, region, demographics and qualifications of the faculty, etc.). 


\section{References}

Alves, H. and Raposo, M. (2010) The influence of university image on student behaviour. International Journal of Education Management 24(1), 73-85.

Arambewela, R. and Hall J. (2009) An empirical model of international student satisfaction, Asia Pacific Journal of Marketing and Logistics, 21(4), 555 - 569.

Armstrong, J.S. (1995) The devil's advocate responses to MBA students' claims that research harms learning. Journal of Marketing 59, 101-106.

Asthana, A. and Biggs, L. (2007) Students pay more but receive less, The Observer, 11 February.

Blanchflower, D. and Oswald, A.J. (2004) Well-being over time in Britain and the USA Journal of Public Economics 61, 359-381.

Boehler, M.L., Rogers, D.A., Schwind, C.J., Mayforth, R., Quin, J., and Williams RG, Dunnington, G. (2006) An investigation of medical student reactions to feedback: a randomized controlled trial Medical Education 32, 367-369.

Borden, V.M. (1995) Segmenting student markets with student satisfaction and priorities survey. Research in Higher Education 36(1), 73-88.

Browne, B., Kaldenberg, D., Browne, W. and Brown, D. (1998) Student as customers: factors affecting satisfaction and assessments of institutional quality, Journal of Marketing for Higher Education, 8(3), 1-14.

Buckley, A., Soilemetzidis, I., and Hillman, N. (2015) The 2015 Student Academic Experience Survey. Higher Education Policy Institute and Higher Education Academy.

Callender, C., Ramsden, P. and Griggs, J. (2014) Review of the National Student Survey Higher Education Funding Council for England.

Chan, G., Miller, P. and Tcha, M. (2005) Happiness in university education International Review of Economics Education 4(1), 20-45.

Chatterton, P. and Goddard, J. (2000) The Response of higher education institutions to regional needs. European Journal of Education 35(4), 475-496.

Collini, S. (2012) What are Universities For? Penguin, London.

Douglas, J. McClelland, R.Davies J. (2008) The development of a conceptual model of student satisfaction with their experience in higher education. Quality Assurance in Education 16(1), 19-35.

Elliott, K.M. and Shin, D. (2002) Student satisfaction: an alternative approach to assessing this important concept. Journal of Higher Education Policy and Management 24(2), 197-209.

Eskildsen, J., Martensen, A., Gronholdt, L. and Kristensen, K. (1999) Benchmarking student satisfaction in higher education based on the ECSI methodology. Proceedings of the TQM for Higher Education Institutions Conference: Higher Education Institutions and the Issue of Total Quality 30-31, August, Verona, pp. 385-402.

Fielding, A., Dunleavy, P.J., and Langan, M. Interpreting context to the UK's national student (satisfaction) survey data for science subjects Journal of Further and Higher Education 34(3), 347-368.

Gibbons, S., Neumayer, E. and Perkins, R. (2015) Student satisfaction, league tables and university applications: evidence from Britain. Economics of Education Review 48, 148-164.

Gibbs, G. (2010) Dimensions of Quality. Higher Education Academy, York.

Gibbs, G. (2012) Implications of 'Dimensions of Quality' in a Market Environment. Higher Education Academy, York. 
Gilman, R. (2001) The Relationship between Life Satisfaction, Social Interest, and Frequency of Extracurricular Activities among Adolescent Students Journal of Youth and Adolescence 30(6), 749-767.

Gornall, L. and Thomas, B. (2014) Professional work and policy reform agendas in a marketised higher education system, in: Gornall, L., Cook, C., Daunton, L., Salisbury, J. and Thomas B. (eds.) Academic Working Lives: Experience, Practice and Change. Bloomsbury, London.

Gruber, T.Fuß, S. Voss, R. and Gläser-Zikuda M. (2010) Examining student satisfaction with higher education services, International Journal of Public Sector Management, 23(2) $105-123$.

Guolla, M. (1999) Assessing the teaching quality to student satisfaction relationship: applied customer satisfaction research in the classroom. Journal of Marketing Theory and Practice 7(3), 87-97.

Hattie, J and Marsh, H.W (1996), The relationship between research and teaching: A meta-analysis, Review of Educational Research, vol. 66, no. 4, pp. 507-542.

Helgesen, $\varnothing$. and Nesset, E. (2007), Images, satisfaction and antecedents: drivers of student loyalty? A case study of a Norwegian university college. Corporate Reputation Review 10(1), 38-59.

Hewson, P. (2011) Preliminary analysis of the national student survey MSOR Communications 11(1), 25-28.

Kay, J., Dunne, E., and Hutchinson, J (2010), Rethinking the values of higher education - students as change agents?, Quality Assuance Agency, London.

Kotler, P. and Fox, K. (1995) Strategic Marketing for Educational Institutions, second edition, Prentice Hall, Englewood Cliffs, New Jersey.

Land, R. and Gordon, G. (2015) Teaching Excellence Initiatives: Modalities and Operational Factors. Higher Education Academy, York.

Langan, A.M., Dunleavy, P., and Fielding, A. (2013) Applying models to national surveys of undergraduate science students: what affects ratings of satisfaction? Education Sciences 3 , 193-207.

Letcher, D.W. and Neves, J. S. (2010) Determinants of undergraduate business student satisfaction, Research in Higher Education Journal, 6, 1-26.

Locke, W. (2014) Shifting Academic Careers: Implications for Enhancing Professionalism in Teaching and Supporting Learning .Higher Education Academy, York.

Mai, L-W. (2005) A comparative study between UK and US: The student satisfaction in higher education and its influential factors Journal of Marketing Management 21, 859-878.

Mavondo, F.T., Tsarenko, Y. and Gabbott, M. (2004) International and local student satisfaction: resources and capabilities perspective. Journal of Marketing for Higher Education 14(1), 4160.

Merritt, D.J. (2012) Bias, the Brain and Student Evaluations of Teaching, St John's Law Review, 82(1), Article 6.

Naftulin, D.H. Ware, J.E. Jr., and Donnelly, F.A. (1973) The Doctor Fox Lecture: A Paradigm of Educational Seduction, Journal of Medical Education, 48, 630-635.

Nguyen, N. and LeBlanc, G. (2001) Image and reputation of higher education institutions in students' retention decisions. International Journal of Education Management 15(6), 303-311.

Oliver, R.L. (1981) Measurement and evaluation of satisfaction processes in retail settings, Journal of Retailing 57(3), 25-48.

Parker, C. and Matthews, B.P. (2001) Customer satisfaction: contrasting academic and consumers' interpretations. Marketing, Intelligence and Planning 19(1), 38-44. 
Palacio, A., Meneses, G. and Pérez, P. (2002) The configuration of the university image and its relationship with the satisfaction of students. Journal of Educational Administration 40(5), 486-505.

Pike, G. (1991) The effects of background, coursework, and involvement on students' grades and satisfaction. Research in Higher Education, 32(1), 15-31.

Sabri, D. (2013) Student Evaluations of Teaching as 'Fact-Totems': the Case of the UK National Student Survey. Sociological Research Online 18(4), 1-15.

Surridge, P. (2008) The national student survey 2005-2007: findings and trends A Report to the Higher Education Funding Council for England

Taylor, C. and McCaig, C. (2014) Evaluating the Impact of Number Controls, Choice and Competition: An Analysis of the Student Profile and the Student Learning Environment in the New Higher Education Landscape. Higher Education Academy, York.

Thornton, T. (2014) Professional recognition: promoting recognition through the Higher Education Academy in a UK higher education institution. Tertiary Education and Management 20(3), 225-238.

Walker, J.T., Vignoles, A., and Collins, M. (2010) Higher Education Academic Salaries in the UK, Oxford Economic Papers, 62, (1), pp. 12-35.

Yorke, M. (2014) The impact of part-time staff on Art \& Design students' ratings of their programmes. Journal of Higher Education Policy and Management 36(5), 557-567.

Yorke, M. (2009) Student experience surveys: some methodological considerations and an empirical investigation. Assessment and Evaluation in Higher Education 34(6), 721-739.

Yorke, M., Orr, S. and Blair, B. (2013) Hit by a perfect storm? Art \& Design in the national student survey. Studies in Higher Education 39(10), 1788-1810.

Zeithaml, V.A., Berry, L.L. and Parasuraman, A. (1993) The nature and determinants of customer expectation of service. Journal of the Academy of Marketing Science 21(1), 1-12. 
Table 1: Average NSS Scores by Subject Area based on Overall Satisfaction

\begin{tabular}{|c|c|c|c|c|c|c|c|}
\hline Subject Area & Mean & $\begin{array}{l}\text { Standard } \\
\text { deviation }\end{array}$ & Min. & $5^{\text {th }}$ Percentile & Median & $95^{\text {th }}$ Percentile & Max. \\
\hline (145) Media studies & 4.02 & 0.37 & 2.6 & 3.4 & 4.1 & 4.56 & 4.8 \\
\hline (115) General engineering & 4.09 & 0.36 & 3.1 & 3.5 & 4.1 & 4.7 & 4.8 \\
\hline (120) Mechanical, aero \& production engineering & 4.12 & 0.32 & 3.4 & 3.6 & 4.1 & 4.6 & 4.8 \\
\hline $\begin{array}{l}\text { (121) IT, systems sciences \& computer software } \\
\text { engineering }\end{array}$ & 4.13 & 0.31 & 3 & 3.64 & 4.1 & 4.66 & 4.9 \\
\hline (125) Area studies & 4.13 & 0.22 & 3.8 & 3.8 & 4.1 & 4.45 & 4.5 \\
\hline (143) Art \& design & 4.14 & 0.31 & 3.2 & 3.68 & 4.1 & 4.6 & 4.9 \\
\hline (144) Music, dance, drama \& performing arts & 4.14 & 0.38 & 2.8 & 3.4 & 4.2 & 4.7 & 5 \\
\hline (117) Mineral, metallurgy \& materials engineering & 4.15 & 0.37 & 3.2 & 3.53 & 4.15 & 4.55 & 4.6 \\
\hline (119) Electrical, electronic \& computer engineering & 4.15 & 0.36 & 2.5 & 3.66 & 4.2 & 4.6 & 4.9 \\
\hline (129) Economics \& econometrics & 4.16 & 0.29 & 3.5 & 3.61 & 4.2 & 4.5 & 4.8 \\
\hline (131) Social work \& social policy & 4.16 & 0.32 & 3.3 & 3.6 & 4.2 & 4.6 & 4.8 \\
\hline (103) Nursing \& allied health professions & 4.17 & 0.32 & 2.6 & 3.6 & 4.2 & 4.6 & 4.8 \\
\hline (137) Modern languages & 4.18 & 0.3 & 3.2 & 3.6 & 4.2 & 4.6 & 4.8 \\
\hline (133) Business \& management studies & 4.19 & 0.29 & 2.8 & 3.7 & 4.2 & 4.6 & 4.9 \\
\hline (134) Catering \& hospitality management & 4.19 & 0.2 & 3.8 & 3.92 & 4.2 & 4.56 & 4.6 \\
\hline (116) Chemical engineering & 4.21 & 0.3 & 3.6 & 3.62 & 4.3 & 4.5 & 4.7 \\
\hline (135) Education & 4.21 & 0.35 & 2.7 & 3.6 & 4.2 & 4.7 & 4.9 \\
\hline (123) Architecture, built environment \& planning & 4.22 & 0.3 & 3.4 & 3.69 & 4.3 & 4.7 & 4.8 \\
\hline (132) Sociology & 4.22 & 0.32 & 2.7 & 3.7 & 4.3 & 4.6 & 4.7 \\
\hline (104) Psychology \& behavioural sciences & 4.23 & 0.26 & 3.2 & 3.7 & 4.2 & 4.6 & 4.9 \\
\hline (105) Health \& community studies & 4.23 & 0.42 & 2.4 & 3.52 & 4.3 & 4.7 & 4.8 \\
\hline (118) Civil engineering & 4.23 & 0.31 & 3.2 & 3.5 & 4.3 & 4.6 & 4.7 \\
\hline (128) Politics \& international studies & 4.23 & 0.31 & 3.1 & 3.7 & 4.3 & 4.6 & 4.7 \\
\hline (108) Sports science \& leisure studies & 4.24 & 0.3 & 3.2 & 3.8 & 4.2 & 4.7 & 4.8 \\
\hline (138) English language \& literature & 4.26 & 0.3 & 2.9 & 3.71 & 4.3 & 4.6 & 4.9 \\
\hline (127) Anthropology \& development studies & 4.27 & 0.28 & 3.8 & 3.8 & 4.35 & 4.67 & 4.7 \\
\hline (130) Law & 4.27 & 0.24 & 3.5 & 3.8 & 4.3 & 4.6 & 4.8 \\
\hline (101) Clinical medicine & 4.28 & 0.31 & 3.5 & 3.63 & 4.3 & 4.7 & 4.8 \\
\hline (110) Agriculture, forestry \& food science & 4.28 & 0.31 & 3.3 & 3.68 & 4.3 & 4.65 & 4.7 \\
\hline (112) Biosciences & 4.28 & 0.28 & 3.5 & 3.8 & 4.3 & 4.7 & 4.9 \\
\hline (124) Geography \& environmental studies & 4.3 & 0.26 & 3.4 & 3.8 & 4.4 & 4.6 & 4.8 \\
\hline (111) Earth, marine \& environmental sciences & 4.31 & 0.3 & 3 & 3.9 & 4.3 & 4.8 & 4.9 \\
\hline (122) Mathematics & 4.32 & 0.22 & 3.7 & 3.9 & 4.3 & 4.7 & 4.7 \\
\hline (113) Chemistry & 4.33 & 0.24 & 3.7 & 3.92 & 4.4 & 4.64 & 4.7 \\
\hline (106) Anatomy \& physiology & 4.34 & 0.23 & 3.6 & 4 & 4.4 & 4.7 & 4.8 \\
\hline (107) Pharmacy \& pharmacology & 4.34 & 0.26 & 3.9 & 3.9 & 4.4 & 4.7 & 4.8 \\
\hline (126) Archaeology & 4.35 & 0.36 & 2.9 & 3.7 & 4.35 & 4.8 & 4.9 \\
\hline (139) History & 4.35 & 0.28 & 3.4 & 3.8 & 4.4 & 4.7 & 5 \\
\hline (140) Classics & 4.35 & 0.22 & 3.8 & 4 & 4.4 & 4.69 & 4.7 \\
\hline (114) Physics & 4.37 & 0.27 & 3.6 & 3.8 & 4.4 & 4.7 & 4.8 \\
\hline (141) Philosophy & 4.38 & 0.19 & 3.9 & 4.1 & 4.4 & 4.6 & 4.8 \\
\hline (142) Theology \& religious studies & 4.41 & 0.28 & 3.4 & 4 & 4.5 & 4.7 & 4.9 \\
\hline (109) Veterinary science & 4.44 & 0.17 & 4.3 & 4.3 & 4.4 & 4.7 & 4.8 \\
\hline (102) Clinical dentistry & 4.65 & 0.14 & 4.4 & 4.48 & 4.7 & 4.83 & 4.9 \\
\hline
\end{tabular}

Notes: This table presents summary measures within each subject area (HESA cost coding) using an unweighted average across all HEIs operating within that cost code based on the conversion of the Likert scale responses for overall satisfaction ( $1=$ strongly disagree, $\ldots, 5=$ strongly agree) to a points score. 
Table 2: Average NSS Scores by Subject Area based on Percentage Satisfied

\begin{tabular}{|c|c|c|c|c|c|c|c|}
\hline Subject Area & Mean & $\begin{array}{l}\text { Standard } \\
\text { deviation }\end{array}$ & Min. & $\begin{array}{l}5^{\text {th }} \\
\text { Percentile }\end{array}$ & Median & $\begin{array}{l}95^{\text {th }} \\
\text { Percentile }\end{array}$ & Max. \\
\hline (145) Media studies & 79.77 & 12.74 & 30 & 56.9 & 82 & 99.1 & 100 \\
\hline $\begin{array}{l}\text { (121) IT, systems sciences \& computer } \\
\text { software engineering }\end{array}$ & 83.45 & 10.02 & 38 & 69 & 83 & 100 & 100 \\
\hline (144) Music, dance, drama \& performing arts & 82.6 & 12.17 & 34 & 59.3 & 84 & 98.7 & 100 \\
\hline $\begin{array}{l}\text { (117) Mineral, metallurgy \& materials } \\
\text { engineering }\end{array}$ & 82.58 & 13.96 & 50 & 58.8 & 84.5 & 98.35 & 100 \\
\hline (143) Art \& design & 82.76 & 10.08 & 50 & 66 & 84.5 & 100 & 100 \\
\hline (115) General engineering & 82.43 & 11.07 & 52 & 64 & 85 & 97.8 & 100 \\
\hline (125) Area studies & 85.42 & 6.08 & 71 & 77.05 & 85 & 93 & 93 \\
\hline (134) Catering \& hospitality management & 85.16 & 6.13 & 67 & 75 & 85 & 93 & 94 \\
\hline (103) Nursing \& allied health professions & 85.32 & 9.96 & 29 & 68 & 86 & 100 & 100 \\
\hline $\begin{array}{l}\text { (120) Mechanical, aero \& production } \\
\text { engineering }\end{array}$ & 83.48 & 10.4 & 58 & 63.65 & 86 & 96 & 100 \\
\hline (129) Economics \& econometrics & 83.87 & 10.27 & 52 & 64.15 & 86 & 95.95 & 100 \\
\hline (131) Social work \& social policy & 84.21 & 10.49 & 50 & 64.9 & 86 & 97 & 100 \\
\hline (108) Sports science \& leisure studies & 86.45 & 9 & 52 & 70.05 & 87.5 & 98.95 & 100 \\
\hline $\begin{array}{l}\text { (119) Electrical, electronic \& computer } \\
\text { engineering }\end{array}$ & 84.15 & 14.18 & 17 & 66.65 & 88 & 98.9 & 100 \\
\hline $\begin{array}{l}\text { (123) Architecture, built environment \& } \\
\text { planning }\end{array}$ & 86.14 & 10.04 & 46 & 65.85 & 88 & 100 & 100 \\
\hline (133) Business \& management studies & 86.04 & 9.56 & 25 & 69 & 88 & 99.55 & 100 \\
\hline (135) Education & 85.92 & 11.03 & 25 & 66.9 & 88 & 100 & 100 \\
\hline (137) Modern languages & 85.83 & 9.69 & 50 & 66.9 & 88 & 98.2 & 100 \\
\hline (104) Psychology \& behavioural sciences & 86.8 & 8.42 & 53 & 69.5 & 89 & 97 & 100 \\
\hline (105) Health \& community studies & 85.29 & 13.78 & 24 & 63.4 & 89 & 100 & 100 \\
\hline (116) Chemical engineering & 87.26 & 9.83 & 69 & 70 & 89 & 100 & 100 \\
\hline (130) Law & 87.96 & 7.85 & 56 & 72.55 & 89 & 98 & 100 \\
\hline (132) Sociology & 86.69 & 10.74 & 38 & 71 & 89 & 98 & 100 \\
\hline (138) English language \& literature & 87.35 & 9.32 & 39 & 70 & 89 & 100 & 100 \\
\hline (111) Earth, marine \& environmental sciences & 88.62 & 9.44 & 44 & 73.6 & 90 & 100 & 100 \\
\hline (112) Biosciences & 88.16 & 8.84 & 58 & 71.35 & 90 & 100 & 100 \\
\hline (118) Civil engineering & 87.14 & 9.06 & 56 & 67.5 & 90 & 97.25 & 100 \\
\hline (122) Mathematics & 89.78 & 6.5 & 73 & 75.75 & 90 & 100 & 100 \\
\hline (124) Geography \& environmental studies & 89.28 & 7.91 & 57 & 74 & 90 & 100 & 100 \\
\hline (127) Anthropology \& development studies & 86.86 & 10.93 & 57 & 67.75 & 90 & 98.95 & 100 \\
\hline (128) Politics \& international studies & 87.2 & 10.25 & 52 & 68.8 & 90 & 100 & 100 \\
\hline (101) Clinical medicine & 87.98 & 9.27 & 64 & 67.25 & 91 & 99.75 & 100 \\
\hline (107) Pharmacy \& pharmacology & 90.11 & 6.76 & 75 & 76.8 & 91 & 99.2 & 100 \\
\hline (113) Chemistry & 89.74 & 7.42 & 67 & 75.6 & 91 & 98.8 & 100 \\
\hline (126) Archaeology & 88.23 & 11.37 & 40 & 65.9 & 91 & 100 & 100 \\
\hline (106) Anatomy \& physiology & 91.11 & 6.33 & 73 & 75.65 & 92 & 99.35 & 100 \\
\hline (110) Agriculture, forestry \& food science & 88.22 & 10.86 & 52 & 68.95 & 92 & 100 & 100 \\
\hline (114) Physics & 90.28 & 7.12 & 70 & 75.65 & 92 & 100 & 100 \\
\hline (139) History & 89.72 & 8.57 & 53 & 73.85 & 92 & 100 & 100 \\
\hline (140) Classics & 90.21 & 5.92 & 77 & 78.6 & 92 & 99.25 & 100 \\
\hline (141) Philosophy & 90.75 & 6.67 & 77 & 79 & 92 & 100 & 100 \\
\hline (109) Veterinary science & 92.88 & 3.56 & 88 & 88.7 & 93 & 97.3 & 98 \\
\hline (142) Theology \& religious studies & 90.86 & 9.47 & 59 & 75.2 & 93.5 & 100 & 100 \\
\hline (102) Clinical dentistry & 96.38 & 2.68 & 90 & 91.5 & 97 & 99.25 & 100 \\
\hline
\end{tabular}

Notes: This table presents summary measures within each subject area (HESA cost coding) using an unweighted average across all HEIs operating within that cost code based on the percentage of students who are satisfied overall. 
Table 3: Satisfaction by Region

\begin{tabular}{|c|c|c|c|c|c|c|c|c|c|c|c|}
\hline \multirow[b]{2}{*}{ Sub-sample } & \multirow[b]{2}{*}{$\mathrm{N}$} & \multicolumn{5}{|c|}{ Mean Score } & \multicolumn{5}{|c|}{ Percent Satisfied } \\
\hline & & Mean & $\begin{array}{l}\text { Std. } \\
\text { dev. }\end{array}$ & Min. & Median & Max. & Mean & $\begin{array}{l}\text { Std. } \\
\text { dev. }\end{array}$ & Min. & Median & Max. \\
\hline Southeast & 582 & 4.261 & 0.303 & 2.6 & 4.3 & 4.9 & 87.74 & 9.59 & 25 & 90 & 100 \\
\hline East Midlands & 321 & 4.249 & 0.295 & 2.4 & 4.3 & 4.9 & 86.89 & 9.72 & 24 & 89 & 100 \\
\hline London & 653 & 4.114 & 0.331 & 2.5 & 4.1 & 4.9 & 82.62 & 11.21 & 17 & 84 & 100 \\
\hline North West & 512 & 4.195 & 0.309 & 2.8 & 4.2 & 4.9 & 85.72 & 9.89 & 34 & 87 & 100 \\
\hline Yorks\& Humber & 407 & 4.245 & 0.270 & 3.3 & 4.3 & 5.0 & 87.50 & 8.72 & 50 & 89 & 100 \\
\hline West Midlands & 370 & 4.235 & 0.291 & 3.2 & 4.3 & 4.9 & 87.11 & 9.28 & 55 & 89 & 100 \\
\hline Southwest & 325 & 4.198 & 0.349 & 2.9 & 4.2 & 4.9 & 85.44 & 11.01 & 40 & 88 & 100 \\
\hline East & 229 & 4.253 & 0.289 & 3.2 & 4.3 & 5.0 & 87.07 & 9.04 & 53 & 88 & 100 \\
\hline Northeast & 168 & 4.270 & 0.269 & 3.1 & 4.3 & 4.9 & 88.11 & 8.09 & 50 & 90 & 100 \\
\hline Wales & 299 & 4.184 & 0.350 & 2.8 & 4.2 & 5.0 & 84.95 & 11.89 & 25 & 87 & 100 \\
\hline Scotland & 491 & 4.220 & 0.327 & 2.6 & 4.2 & 4.9 & 86.07 & 10.48 & 29 & 88 & 100 \\
\hline Northern Ireland & 107 & 4.377 & 0.377 & 3.4 & 4.4 & 4.8 & 90.50 & 7.87 & 52 & 92 & 100 \\
\hline \multicolumn{2}{|c|}{ F-test of equal mean in all regions } & \multicolumn{5}{|c|}{ F-statistic:11.325 (p-value: 0.000$)$} & \multicolumn{5}{|c|}{ F-statistic:11.944 (0.000) } \\
\hline Entire sample & 4465 & 4.216 & 0.315 & 2.4 & 4.3 & 5.0 & 86.13 & 10.20 & 17 & 88 & 100 \\
\hline
\end{tabular}

Notes: This table reports summary statistics for overall satisfaction (based on responses to question 22 in the survey) by region. The middle panel shows the

results based on the Likert scale responses while the right panel is based on the percentage of students who are satisfied. The penultimate row reports the results from an F-test for equal satisfaction across all regions while the final row presents overall satisfaction summary statistics for the entire sample. 
Table 4: Correlation between Sub-Categories - Average (1-5) Scores

\begin{tabular}{|c|c|c|c|c|c|c|c|}
\hline & $\begin{array}{r}\text { Assessment } \\
\& \text { feedback }\end{array}$ & $\begin{array}{r}\text { Academic } \\
\text { support }\end{array}$ & $\begin{array}{r}\text { Organisation } \\
\& \\
\text { management } \\
\end{array}$ & $\begin{array}{r}\text { Learning } \\
\text { resources }\end{array}$ & $\begin{array}{r}\text { Personal } \\
\text { development }\end{array}$ & $\begin{array}{r}\text { Overall } \\
\text { satisfaction }\end{array}$ & $\begin{array}{r}\text { Satisfaction } \\
\text { with the } \\
\text { Students' } \\
\text { Union }\end{array}$ \\
\hline $\begin{array}{r}\text { Teaching on } \\
\text { my course }\end{array}$ & 0.657 & 0.752 & 0.599 & 0.312 & 0.645 & 0.827 & 0.187 \\
\hline $\begin{array}{l}\text { Assessment } \\
\& \text { feedback }\end{array}$ & & 0.694 & 0.565 & 0.258 & 0.531 & 0.666 & 0.223 \\
\hline $\begin{array}{r}\text { Academic } \\
\text { support }\end{array}$ & & & 0.649 & 0.413 & 0.665 & 0.797 & 0.275 \\
\hline $\begin{array}{r}\text { Organisation \& } \\
\text { management }\end{array}$ & & & & 0.334 & 0.425 & 0.749 & 0.242 \\
\hline $\begin{array}{r}\text { Learning } \\
\text { resources }\end{array}$ & & & & & 0.396 & 0.407 & 0.311 \\
\hline $\begin{array}{r}\text { Personal } \\
\text { development }\end{array}$ & & & & & & 0.680 & 0.287 \\
\hline $\begin{array}{r}\text { Overall } \\
\text { satisfaction }\end{array}$ & & & & & & & 0.263 \\
\hline
\end{tabular}

Notes: This table presents the Pearson correlations between the average scores awarded to each section of the NSS questionnaire, based on the conversion of the Likert scale responses $(1=$ strongly disagree, $\ldots, 5=$ strongly agree $)$ to a points score. 
Table 5: Correlation between Sub-Categories - Percent Satisfied

\begin{tabular}{|c|c|c|c|c|c|c|c|}
\hline & $\begin{array}{l}\text { Assessment } \\
\text { \& feedback }\end{array}$ & $\begin{array}{r}\text { Academic } \\
\text { support }\end{array}$ & $\begin{array}{r}\text { Organisation } \\
\& \\
\text { management }\end{array}$ & $\begin{array}{r}\text { Learning } \\
\text { resources }\end{array}$ & $\begin{array}{r}\text { Personal } \\
\text { development }\end{array}$ & $\begin{array}{r}\text { Overall } \\
\text { satisfaction }\end{array}$ & $\begin{array}{r}\text { Satisfaction } \\
\text { with the } \\
\text { Students' } \\
\text { Union }\end{array}$ \\
\hline $\begin{array}{l}\text { Teaching on } \\
\text { my course }\end{array}$ & 0.565 & 0.678 & 0.555 & 0.240 & 0.537 & 0.768 & 0.185 \\
\hline $\begin{array}{r}\text { Assessment } \\
\text { \& feedback }\end{array}$ & & 0.639 & 0.508 & 0.182 & 0.444 & 0.569 & 0.186 \\
\hline $\begin{array}{r}\text { Academic } \\
\text { support }\end{array}$ & & & 0.584 & 0.338 & 0.578 & 0.707 & 0.261 \\
\hline $\begin{array}{r}\text { Organisation \& } \\
\text { management } \\
\text { Learning }\end{array}$ & & & & 0.263 & 0.358 & 0.684 & 0.250 \\
\hline $\begin{array}{r}\text { resources } \\
\text { Personal }\end{array}$ & & & & & 0.326 & 0.318 & 0.277 \\
\hline $\begin{array}{r}\text { development } \\
\text { Overall } \\
\text { satisfaction }\end{array}$ & & & & & & 0.567 & $\begin{array}{l}0.276 \\
0.236\end{array}$ \\
\hline
\end{tabular}

Notes: This table presents the Pearson correlations between the average scores awarded to each section of the NSS questionnaire, based on The percentage of students who are satisfied in each case. 
Table 6: Which Individual Areas Drive Overall Satisfaction?

\begin{tabular}{lcc}
\hline Explanatory Variable & $\begin{array}{c}\text { Satisfaction } \\
\text { Score }\end{array}$ & $\begin{array}{c}\text { Percent } \\
\text { Satisfied }\end{array}$ \\
\hline Constant & -1.073 & -15.179 \\
& $(0.055)^{* * *}$ & $(1.563)^{* * *}$ \\
The teaching on my course & 0.489 & 0.524 \\
& $(0.016)^{* * *}$ & $(0.021)^{* * *}$ \\
Assessment and feedback & 0.030 & 0.024 \\
& $(0.011)^{* * *}$ & $(0.012)^{* *}$ \\
Academic support & 0.194 & 0.181 \\
& $(0.017)^{* * *}$ & $(0.020)^{* * *}$ \\
Organisation and management & 0.286 & 0.262 \\
& $(0.010)^{* * *}$ & $(0.013)^{* * *}$ \\
Learning resources & 0.055 & 0.058 \\
& $(0.010)^{* * *}$ & $(0.013)^{* * *}$ \\
Personal development & 0.212 & 0.159 \\
Satisfaction with the Students' Union & $(0.015)^{* * *}$ & $(0.017)^{* * *}$ \\
& 0.004 & -0.004 \\
\hline $\mathrm{R}^{2}$ & $(0.006)$ & $(0.006)$ \\
$\mathrm{N}$ & 0.83 & 0.72 \\
\hline
\end{tabular}

Notes: This table presents the parameter estimates (with standard errors in parentheses) for regressions where the dependent variable is overall satisfaction (the response to question 22 in the survey), based on either the Likert scale (middle column) or percentage of students who are satisfied (right hand column). The explanatory variables are the average scores for each section on the form. Each data point represents a course or course collection at a higher education institution. ${ }^{*}, *$ and ${ }^{* * *}$ denote significance at the $10 \%, 5 \%$ and $1 \%$ levels respectively. 
Table 7: Pairwise Comparisons of NSS Scores by Sub-groupings

\begin{tabular}{|c|c|c|c|c|c|c|c|c|c|c|c|}
\hline \multirow[b]{2}{*}{ Sub-sample } & \multicolumn{6}{|c|}{ Mean Score } & \multicolumn{5}{|c|}{ Percent Satisfied } \\
\hline & $\mathrm{N}$ & Mean & $\begin{array}{l}\text { Std. } \\
\text { dev. }\end{array}$ & Min. & Median & Max. & Mean & Std. dev. & Min. & Median & Max. \\
\hline Part-time & 201 & 4.242 & 0.337 & 2.6 & 4.3 & 4.9 & 86.75 & 11.31 & 29 & 89 & 100 \\
\hline Full-time & 4264 & 4.215 & 0.314 & 2.4 & 4.3 & 5.0 & 86.10 & 10.14 & 17 & 88 & 100 \\
\hline t-test: part-time vs full-time & & \multicolumn{5}{|c|}{ t-statistic: -1.113 (p-value: 0.267$)$} & \multicolumn{5}{|c|}{ t-statistic: -0.800 ( $p$-value: 0.425$)$} \\
\hline Russell-group & 1024 & 4.261 & 0.279 & 2.7 & 4.3 & 5.0 & 87.66 & 8.88 & 38 & 90 & 100 \\
\hline Not Russell group & 3440 & 4.202 & 0.323 & 2.4 & 4.2 & 5.0 & 85.68 & 10.52 & 17 & 88 & 100 \\
\hline t-test: Russell vs not Russell & & \multicolumn{5}{|c|}{ t-statistic: -5.721 (p-value: 0.000$)$} & \multicolumn{5}{|c|}{ t-statistic: -5.992 (p-value: 0.000$)$} \\
\hline Specialist institution & 77 & 4.190 & 0.324 & 3.2 & 4.2 & 4.9 & 84.75 & 10.36 & 45 & 86 & 100 \\
\hline Not specialist institution & 4387 & 4.216 & 0.315 & 2.4 & 4.3 & 5.0 & 86.16 & 10.19 & 17 & 88 & 100 \\
\hline t-test: specialised versus not & & \multicolumn{5}{|c|}{ t-statistic: 0.698 (p-value: 0.486$)$} & \multicolumn{5}{|c|}{ t-statistic: 1.184 (p-value: 0.238$)$} \\
\hline University in QS Top 400 & 1662 & 4.273 & 0.280 & 2.7 & 4.3 & 5.0 & 88.03 & 8.90 & 25 & 90 & 100 \\
\hline University not in QS Top 400 & 2802 & 4.182 & 0.329 & 2.4 & 4.2 & 5.0 & 85.01 & 10.74 & 17 & 87 & 100 \\
\hline t-test in QS top 400 vs not & & \multicolumn{5}{|c|}{ t-statistic: -9.824 (p-value: 0.000$)$} & \multicolumn{5}{|c|}{ t-statistic: -10.133 (p-value: 0.000$)$} \\
\hline New University & 2318 & 4.165 & 0.333 & 2.4 & 4.2 & 4.9 & 84.54 & 10.94 & 17 & 86 & 100 \\
\hline Old University & 2146 & 4.271 & 0.284 & 2.7 & 4.3 & 5.0 & 87.85 & 9.02 & 25 & 90 & 100 \\
\hline t-test new university vs old & & \multicolumn{5}{|c|}{ t-statistic: 11.469 (p-value: 0.000$)$} & \multicolumn{5}{|c|}{ t-statistic: 11.061 (p-value: 0.000$)$} \\
\hline Entire sample & 4465 & 4.216 & 0.315 & 2.4 & 4.3 & 5.0 & 86.13 & 10.20 & 17 & 88 & 100 \\
\hline
\end{tabular}


Table 8: Summary Statistics of Synthetic Overall Responses Compared with Actual Values

\begin{tabular}{|c|c|c|c|c|c|}
\hline \multicolumn{6}{|c|}{ Panel A: Summary Statistics } \\
\hline & Actual Score (1-5) & Synthetic Score (1-5) & \multirow{2}{*}{$\begin{array}{r}\text { Actual \% Satisfied } \\
86.132\end{array}$} & \multicolumn{2}{|c|}{ Synthetic \% Satisfied } \\
\hline Mean & 4.216 & 4.216 & & & 86.132 \\
\hline Std. dev. & 0.315 & 0.286 & 10.196 & & 8.680 \\
\hline Skewness & -0.859 & -0.463 & -1.441 & & -0.974 \\
\hline Kurtosis & 1.711 & 1.258 & 3.642 & & 1.884 \\
\hline \multicolumn{6}{|c|}{ Panel B: Top Ten Fallers on Actual Score } \\
\hline \multirow[t]{2}{*}{ Institution (University) } & & & $\begin{array}{l}\text { Synthetic } \\
\text { Value for }\end{array}$ & $\begin{array}{r}\text { Actual } \\
\text { Value for }\end{array}$ & Difference \\
\hline & Course & & Q22 & Q22 & \\
\hline Southampton Solent & Ocean Sciences & & 3.2 & 4.2 & -1.0 \\
\hline London Metropolitan & Human Resource Mana & ement & 4.1 & 4.6 & -0.5 \\
\hline East London & Molecular Biology, Biop & רysics and Biochemistry & 3.3 & 3.8 & -0.5 \\
\hline Wolverhampton & Finance & & 4.0 & 4.5 & -0.5 \\
\hline Hull & Theology and Religious & tudies & 4.1 & 4.6 & -0.5 \\
\hline Staffordshire & Fine Art & & 3.8 & 4.3 & -0.5 \\
\hline Stirling & Human Resource Mana & ement & 4.3 & 4.7 & -0.4 \\
\hline Roehampton & Human Resource Mana & ement & 3.9 & 4.3 & -0.4 \\
\hline Liverpool & Animal Science & & 3.8 & 4.2 & -0.4 \\
\hline Canter. Christ Church & Others in Biological Scie & hces & 4.1 & 4.5 & -0.4 \\
\hline \multicolumn{6}{|c|}{ Panel C: Top Ten Risers on Actual Score } \\
\hline Bournemouth & Human and Social Geog & aphy & 3.7 & 2.9 & 0.8 \\
\hline Bedfordshire & Fine Art & & 4.3 & 3.5 & 0.8 \\
\hline De Montfort & Anatomy, Physiology an & d Pathology & 3.1 & 2.4 & 0.7 \\
\hline Greenwich & Nutrition & & 4.0 & 3.4 & 0.6 \\
\hline Highlands \& Islands & Building & & 4.2 & 3.6 & 0.6 \\
\hline Chester & Social Policy & & 3.9 & 3.3 & 0.6 \\
\hline Edinburgh Napier & Economics & & 4.1 & 3.5 & 0.6 \\
\hline Manchester Metrop. & Dance & & 3.4 & 2.8 & 0.6 \\
\hline Ulster & Aural and Oral Sciences & & 4.0 & 3.4 & 0.6 \\
\hline Lancaster & Music & & 4.0 & 3.4 & 0.6 \\
\hline \multicolumn{6}{|c|}{ Panel D: Top Ten Fallers on \% Satisfied } \\
\hline Southampton Solent & Ocean Sciences & & 60 & 100 & -39.8 \\
\hline Uni. of Arts, London & Management studies & & 61 & 82 & -20.6 \\
\hline Sheffield Hallam & Electronic and Electrical & Engineering & 78 & 98 & -20.2 \\
\hline Liverpool & Animal Science & & 74 & 94 & -20.2 \\
\hline Hull & Theology and Religious & tudies & 80 & 100 & -19.8 \\
\hline Sheffield Hallam & Planning (Urban, Rural & nd Regional) & 80 & 100 & -19.6 \\
\hline Liverp. John Moores & Electronic and Electrical & Engineering & 80 & 100 & -19.6 \\
\hline East London & Molecular Biology, Biop & nysics and Biochemistry & 53 & 72 & -18.6 \\
\hline Brighton & Politics & & 81 & 100 & -18.6 \\
\hline Surrey & Dance & & 82 & 100 & -18.4 \\
\hline \multicolumn{6}{|c|}{ Panel E: Top Ten Risers on \% Satisfied } \\
\hline East London & Electronic and Electrical & Engineering & 51 & 17 & 33.8 \\
\hline Bournemouth & Human and Social Geog & aphy & 70 & 40 & 29.5 \\
\hline Sheffield & Theology and Religious & tudies & 90 & 62 & 28.5 \\
\hline Bedfordshire & Fine Art & & 82 & 55 & 27.1 \\
\hline Wales Trinity St. Dav. & Accounting & & 51 & 25 & 25.6 \\
\hline Manchester Met. & Dance & & 59 & 34 & 24.6 \\
\hline Arts Bournemouth & Media studies & & 71 & 47 & 24.4 \\
\hline Canter. Christ Church & Publicity studies & & 54 & 30 & 24.1 \\
\hline Newcastle upon Tyne & Nutrition & & 76 & 52 & 23.7 \\
\hline Chester & Social Policy & & 77 & 53 & 23.7 \\
\hline
\end{tabular}


Table 9: An Analysis of the Component and Overall Satisfaction Scores for the Biggest Changes between the Actual and Synthetic Overall Scores

\begin{tabular}{|c|c|c|c|c|}
\hline \multirow[t]{2}{*}{ Aspect under Evaluation } & $\begin{array}{l}\text { Satisfaction } \\
\text { Score }\end{array}$ & $\begin{array}{l}\text { Percent } \\
\text { Satisfied }\end{array}$ & Satisfaction Score & $\begin{array}{l}\text { Percent } \\
\text { Satisfied }\end{array}$ \\
\hline & \multicolumn{2}{|c|}{$\begin{array}{c}\text { Ocean Sciences, } \\
\text { Southampton Solent Uni. }\end{array}$} & \multicolumn{2}{|c|}{$\begin{array}{c}\text { Electronic and Electrical } \\
\text { Engineering, Uni. Of East London }\end{array}$} \\
\hline The teaching on my course & 3.7 & 78 & 3.3 & 53 \\
\hline Assessment and feedback & 3.4 & 58 & 2.7 & 34 \\
\hline Academic support & 3.4 & 64 & 3.4 & 53 \\
\hline Organisation and management & 2.7 & 33 & 3.5 & 61 \\
\hline Learning resources & 4.1 & 87 & 3.7 & 67 \\
\hline Personal development & 3.2 & 47 & 3.6 & 51 \\
\hline Satisfaction with the Students' Union & 2.4 & 40 & 3.0 & 50 \\
\hline Actual Overall Score (Q22) & 4.2 & 100 & 2.8 & 17 \\
\hline Number of respondents & 10 & 10 & 12 & 12 \\
\hline Total Population & 12 & 12 & 17 & 17 \\
\hline Proposed Synthetic Overall Score & 3.2 & 60 & 3.3 & 51 \\
\hline
\end{tabular}

Table 10: Average over all Courses and Institutions of the Standard Deviation over time in Actual and Synthetic Scores

\begin{tabular}{cccc}
\hline & $\begin{array}{c}\text { Synthetic overall } \\
\text { score }\end{array}$ & $\begin{array}{c}\text { Actual overall } \\
\text { score (Q22) }\end{array}$ & $\begin{array}{c}\text { \% of course collections for which the synthetic } \\
\text { overall score has a lower standard deviation }\end{array}$ \\
\hline $\begin{array}{c}\text { Std. dev. of scores } \\
\text { Std dev. of \% satisfied }\end{array}$ & 0.196 & 0.208 & 57.6 \\
\hline
\end{tabular}

